\title{
Duties in Permanent Sovereignty over Natural Wealth and Resources and Petroleum Development in Nigeria: Need to Domesticate Benchmarked International Standards and Practices in the Country
}

\author{
Edward T. Bristol-Alagbariya \\ Associate Dean \& Senior Multidisciplinary Lecturer, Faculty of Law, University of Port Harcourt, \\ NIGERIA; and Visiting Research Fellow, Centre for Energy, Petroleum \& Mineral Law and Policy \\ (CEPMLP), Graduate School of Natural Resources Law, Policy \& Management, University of Dundee, \\ Scotland, UNITED KINGDOM.
}

\begin{abstract}
This paper examines the duties of resources-rich developing countries inherent in Permanent Sovereignty over Natural Wealth and Resources (PSNWR) in the context of the laws and other forms of government regulatory frameworks, such as government institutional regulatory frameworks, governing petroleum development in Nigeria. It emphasises the significance of good, dynamic and effective laws, alongside viable, strong and efficient institutions in the governance of major natural resources extractive industrial development operations (EIOs) in Nigeria. It rationalises how and why petroleum and other EIOs regulatory frameworks in Nigeria should be designed and implemented in conformity with widely acknowledged and accepted benchmarked international EIOs regulatory mechanisms, such as guidelines, norms, rules, standards and practices, which are soft law instruments that are increasingly governing EIOs in sovereign states around the globe, in the ongoing era of sustainable development (SD). It recommends a need for domestication of such regulatory mechanisms governing petroleum resources development operations and other EIOs in Nigeria, as doing so would boost good environmental governance and overall government social responsibility, towards robust, efficient and effective accomplishment of the duties of Nigeria embedded in PSNWR, in the course of the resources development operations in the oil-rich Niger Delta region. Doing so would thus boost human wellbeing, good governance and environmentally-sound and socio-economically equitable SD in Nigeria, towards overall public good and allembracing prosperity in the country.

Keywords: Permanent Sovereignty over Natural Wealth and Resources (PSNWR), Petroleum Development, Extractive Industrial Operations (EIOs), Good Environmental Governance (GEG), Government Social Responsibility (GSR), Good Governance and Sustainable Development (SD).
\end{abstract}

DOI: $10.7176 / \mathrm{JLPG} / 92-09$

Publication date: December $31^{\text {st }} 2019$

\section{Introduction}

Permanent Sovereignty over Natural Wealth and Resources (PSNWR) unfolded as an international political claim and a principle of international law, which is rooted in international human rights law and the principles of self-determination and economic sovereignty. The principle presupposes absolute, inalienable, free and full, and thus unfettered right of newly independent developing countries over their natural wealth and resources. ${ }^{1}$ It was enshrined in the UN General Assembly (UNGA) Resolution 1803 (XVII) of 14 December, 1962, entitled: 'Permanent Sovereignty over Natural Resources'. ${ }^{2}$ By virtue of PSNWR, the UNGA promotes the unfettered sovereign right of resources-rich developing countries to explore and exploit their natural resources as well as manage the wealth accruing from the development of these resources for development of their countries and the wellbeing of their citizens. ${ }^{3}$

Rights and duties of resources-rich developing countries, regarding the development of natural resources and the management of the wealth accruing from the development of these resources are embedded in the Eight Articles of PSNWR. ${ }^{4}$ For instance, Article 1 of the UNGA Resolution on PSNWR provides that the duties inherent in the inalienable right of a resources-rich state are principally those of national development and the wellbeing of the citizens. Thus, the duties inherent in PSNWR are about the wellbeing of developing countries and their citizenry, especially the wellbeing of the citizens from whose communal homelands natural resources

\footnotetext{
${ }^{1}$ N. Schrijver, Sovereignty over Natural Resources: Balancing Rights and Duties (Cambridge University Press 1997), 1-3.

${ }^{2}$ Office of the United Nations High Commissioner for Human Rights (UN OHCHR), 'General Assembly Resolution 1803 (XVII) of 14 December 1962, 'Permanent Sovereignty Natural Resources' $<$ https://www.ohchr.org/EN/ProfessionalInterest/pages/NaturalResources.aspx $>$ Accessed 20 November, 2019.

${ }^{3}$ Ibid.

${ }^{4}$ Ibid.
} 
of these countries are being exploited and/or developed for the benefit of their countries. ${ }^{1}$ However, although rights and duties are closely related, and cannot be separated from each other, ${ }^{2}$ governments of resources-rich developing countries such as Nigeria are promptly exercising their rights of PSNWR to exploit the natural resources of their countries and to manage the wealth accruing from the exploitation of these resources, without equally performing their corresponding duties to cater for the wellbeing of their countries and citizens, including the wellbeing of the geographical regions where the natural resources being so exploited are derived. It is against this background that this paper examines how Nigeria, represented by its governments, may either improve on its performance or effectively perform its duties ingrained in PSNWR with regard to petroleum development operations in the oil-rich Niger Delta region, in the context of the legal and institutional frameworks governing PSNWR in the country.

The twin subject-matters of laws and institutions governing PSNWR concerning petroleum development in Nigeria are important because laws and institutions (established by enabling laws) are crucial to the achievement and sustenance of civilisation, and due process, order, peace and stability, towards overall public good in any given society. ${ }^{3}$ Thus, by virtue of good, dynamic and effective laws, policies, standards and programmes, viable and efficient institutions are able to embark on government social responsibility (GSR) measures, to strengthen governance, so as to achieve generic public good, overall prosperity and sustainable development (SD) in global states, Nigeria not being an exception. ${ }^{4}$ The Report of the World Commission on Environment and Development (WCED) otherwise called the Brundtland Commission, entitled Our Common Future, defines SD as the development which seeks to meet the needs of the present generation without compromising the ability of future ones to meet their own needs. ${ }^{5}$

In order to widely examine the legal and institutional frameworks associated with PSNWR, in the context of petroleum development in Nigeria, it is pertinent to consider relevant global and other international regulatory frameworks premised on the ongoing and progressively advancing effort of the UN on the environment and development towards SD.

\section{Global and Other International Regulatory Frameworks Associated with PSNWR}

The global regulatory frameworks directly or indirectly associated with PSNWR include the UN General Assembly (UNGA) Resolution 1803 (XVII) of 14 December, 1962, on PSNWR; the UNGA Resolution UNGA Resolution 47/135 of 18 December, 1992, on the Rights of Persons Belonging to National or Ethnic, Religious and Linguistic Minorities; and the UN Global Compact. Other global regulatory frameworks associated with PSNWR include the UN Stockholm, Rio de Janeiro, Johannesburg and Rio de Janeiro process (put otherwise, as the UN SRJR process) on the environment and development designed to achieve SD, which have the UN system as their institutional framework. The UN SRJR process refers to the UN Conference on the Human Environment (UNCHE), held at Stockholm, in 1972 (following which the assembly of the world community took place in Nairobi, Kenya, from 10-18 May, 1982, when the UN Nairobi Declaration of 1982 was reached); UN Conference on Environment and Development (UNCED), held at Rio de Janeiro, in 1992; the World Summit on SD (WSSD), held at Johannesburg, in 2002; and the UN Conference on Sustainable Development (UNCSD), held again in Rio de Janeiro, in 2012, and their progressively ongoing processes. The initiative of the UN Secretary-General for setting-up the UN Global Compact, and efforts of the WCED, ${ }^{6}$ the UN Environment Programme (UNEP) ${ }^{7}$ as well as the Division for SD Goals (DSDGs) ${ }^{8}$ in the UN Department of Economic and Social Affairs (UNDESA), which acts as Secretariat for the UNSD Goals (UNSDGs) in the UN system, are remarkable in the context of the UN SRJR process and its ongoing processes. Fall-outs of the UN SRJR process and its progressively ongoing processes are widely acknowledged and accepted benchmarked SD-oriented soft law regulatory mechanisms, such as guidelines, norms, rules, standards and practices, which are increasingly

\footnotetext{
${ }^{1}$ Ibid; Article 1, UNGA Resolution on PSNWR.

${ }^{2}$ H. T. Terry, 'Legal Duties and Rights' [1903] 12 (4) The Yale Law Journal, 185-212; D. Lyons, 'The Correlativity of Rights and Duties' [1970] 4 (1) Noûs, 45-55.

${ }^{3}$ Goal 16, UN Sustainable Development Goals (UNSDGs) captioned 'Peace, Justice and Strong Institutions'; J. Walsh, 'How Power and Institutions Affect Development'<https://www.weforum.org/agenda/2015/03/how-power-and-institutions-affect-development/> Accessed 20 November, 2019

Ibid; V. E. Dike, 'Governance and Nigeria's Weak Institutions: Is the 2020 Project Achievable?'<http://www.gamji.com/article8000/NEWS8396.htm> Accessed 20 November, 2019; B. Parks et al, 'Future Development: Why developing countries get stuck with weak institutions and how foreign actors can help' $<$ https://www.brookings.edu/blog/futuredevelopment/2017/07/26/why-developing-countries-get-stuck-with-weak-institutions-and-how-foreign-actors-can-help/> Accessed 20 November, 2019; Public Sector Group Poverty Reduction and Economic Management (PREM) Network, Reforming Public Institutions and Strengthening Governance (The International Bank for Reconstruction and Development [IBRD]/The World Bank 2000).

${ }^{5}$ WCED, Our Common Future (Oxford University Press 1987) 8, 40 and 43.

${ }^{6}$ WCED (n9).

${ }^{7}$ Homepage of UNEP < https://www.unenvironment.org/> Accessed 20 November, 2019.

8 UN Department of Economic and Social Affairs (UNDESA), 'Division for Sustainable Development Goals' $<$ https://www.un.org/development/desa/en/about/desa-divisions/sustainable-development.html>Accessed 20 November, 2019.
} 
governing developmental plans, polices and projects, including programmes (PPPs) associated with the environment in member-states of the UN around the globe.

Apart from the foregoing and other global regulatory standards and practices associated with PSNWR, there are other benchmarked international SD-oriented regulatory frameworks governing major natural resources extractive industrial operations (EIOs) and other forms of natural resources development operations in developing countries. These include the International Finance Corporation (IFC) sustainability framework, which may be exemplified by the IFC performance standards on environmental and social sustainability that the IFC employ to enhance its financial returns, ensure risk management and to help its investors achieve positive impacts, such as to protect the environment and to provide social investments, so as to achieve greater positive development impacts to enhance business sustainability and for the good and wellbeing of society. Among other resources, the IFC sustainability framework comprises eight performance standards on environmental and social sustainability, which IFC clients are to comply with throughout the life of an investment associated with it. These Performance Standards, which apply to all IFC investments and advisory clients, define the responsibilities of IFC clients for managing their environmental and social risks. These performance standards provide guidance on how to identify risks and impacts, and are designed to help avoid, mitigate, and manage risks and impacts, to enhance development opportunities, as a way of doing business in a sustainable way. Accordingly, these are regulatory standards and practices, which are increasingly being designed and promoted by global mining and minerals sector organisations such as the Global Mining Guidelines Group (GMGG), Global Mining Sustainability framework and the Global Mining Institute, which are governing EIOs, which include petroleum development operations, around the globe.

The persuasive nature of these global and other international regulatory guidelines, norms, rules and standards, as well as the findings and recommendations of key stakeholder-groups of EIOs, such as the Mining, Minerals and SD (MMSD) project that took place in 2000, ${ }^{1}$ and the World Bank Group (WBG) that embarked on the WBG Extractive Industries Review (EIR) between 2000 and 2004, ${ }^{2}$ are distinct from the compelling nature of the domestic hard laws and institutional frameworks of Nigeria discussed hereunder. Nevertheless, these soft law $^{3}$ mechanisms governing PSNWR and thus EIOs such as petroleum resources development operations in Nigeria and other global sovereign states are in the ongoing era of SD, positively transforming domestic legal and institutional frameworks and practices of global states. Benchmarked global SD-oriented and other benchmarked international guidelines, norms, policies, rules, standards and practices governing EIOs are increasingly having the compelling force and effects of hard laws ${ }^{4}$ in Nigeria and many other resources-rich developing countries, such that they are transforming developmental PPPs associated with the environment, towards good environmental governance (GEG), premised on careful, sound and prudent protection, development and management of the environment, ecological conservation and preservation of ecosystems and ecosystem services, as well as human wellbeing and the wellbeing of other resources of nature around the globe. These UN-oriented and other international EIOs regulatory soft law modes of conduct and practices are increasingly transforming developmental PPPs in resources-rich developing countries like Nigeria and thereby enhancing SD, centred on human wellbeing, towards a fairer, more just, sustainable and peaceful world. ${ }^{5}$

\subsection{The African Charter on Human and Peoples' Rights (ACHPR) as an African Continental Legal Instrument and Nigeria's (Domestic) Law Associated with this Study}

The African Charter on Human and Peoples' Rights (ACHPR), also known as the 'Banjul Charter', 1981, is another legal instrument that relates to PSNWR.

This Charter is an international human rights instrument, which is intended to promote, protect and enforce

\footnotetext{
${ }^{1}$ International Institute for Environment and Development (IIED) and World Business Council for Sustainable Development (WBCSD), Breaking New Ground: Mining, Minerals, and Sustainable Development: The Report of the MMSD Project (Earthscan 2002).

${ }^{2}$ World Bank Group, 'Striking a Better Balance - The World Bank Group and Extractive Industries: The Final Report of the Extractive Industries Review, World Bank Group Management $<$ http://documents.worldbank.org/curated/en/961241468781797388/pdf/300010GLB.pdf> Accessed 20 November, 2019.

${ }^{3}$ J. B. Skjærseth et al, 'Soft Law, Hard Law, and Effective Implementation of International Environmental Norms' [2006] 6 (3) Global Environmental Politics, 104-120; A. T. Guzman and T. L. Meyer, 'International Soft Law' [2010] 2 (1) The Journal of Legal Analysis, 171225.

${ }^{4}$ E. T. Bristol-Alagbariya, Petroleum Development \& the Environment in Rivers State Nigeria: Fallouts of the UNEP Report on Ogoniland, Environmental Regulatory Standards \& Sustainable Development Laws \& Practices (LAP LAMBERT Academic Publishing 2018) 1, 43, 66 and 74; K. W. Abbott and D. Snidal, 'Hard and Soft Law in International Governance' [2000] 54 (3) International Organization, $421-456$.

${ }^{5}$ The UK Department for Environment, Food and Rural Affairs (DEFRA), Sustainable Development Indicators in Your Pocket 2009: An Update of the UK Government Strategy Indicators (DEFRA/Crown 2009) 119; Economic and Social Research Council (ESRC) Group on Wellbeing in Developing Countries (WeD), Centre for Development Studies, University of Bath, Somerset, England, United Kingdom, 'Working Papers' < http://www.bath.ac.uk/soc-pol/welldev/research/working.htm> Accessed 20 November, 2019; homepage of the Earth Charter Initiative <http://earthcharter.org/> Accessed 20 November, 2019; International Finance Corporation (IFC), 'Ensuring Local Communities Benefit from $\quad$ Extractive Industries $<$ https://www.ifc.org/wps/wcm/connect/topics_ext_content/ifc_external_corporate_site/sustainability-at-ifc/publications/sba-project-
} mriperu $>$ Accessed 20 November, 2019. 
human rights and basic freedoms in Africa. ${ }^{1}$ The Charter is the African version of the Universal Declaration of Human Rights (UDHR), 1948, enacted on the platform of the Organisation of African Union (OAU, now African Union [AU]) on 19 January, 1981, in Banjul, the Capital City of Gambia, in West Africa, to give effect to the UDHR in Africa. The ACHPR vis-à-vis the African regional system of human rights is one of the best conceived and most robust regional human rights' systems around the globe, ${ }^{2}$ especially for being autochthonous and as such rooted in African historical, cultural, traditional and moral values and the process of colonial liberation. It was ratified by Nigeria, through domestication into the Nigerian legal system on 17 March, 1983, as the ACHPR (Ratification and Enforcement) Act, in order to enhance the promotion, protection and enforcement of human rights in Nigeria. So, the Nigerian version of the ACHPR is the ACHPR (Ratification and Enforcement) Act, $1983 .{ }^{3}$ This is why the ACHPR is considered as an African-wide international legal instrument as well as a distinct domestic law of Nigeria, where the instrument applies by virtue of its specific incorporation and adoption into the Nigerian legal system as the ACHPR (Ratification and Enforcement) Act, based on Section 12 of the 1999 Constitution of the Federal Republic of Nigeria (CFRN) (as amended) captioned 'Implementation of Treaties'.

In Nigeria, human rights are bifurcated into civil and political rights (provided for in Chapter Four of the 1999 CFRN [as amended], captioned 'Fundamental Rights', and Economic and Socio-cultural (ECOSOC) rights (provided for in Chapter Two of the Constitution, captioned 'Fundamental Objectives and Directive Principles of State Policy'), although ECOSOC rights are non-justiciable and thus unenforceable by citizens against governments in the country. ${ }^{4}$

Considering that PSNWR is rooted in the human rights of a people to self-determination, there are certain provisions of the ACHPR and the ACHPR (Ratification and Enforcement) Act, 2004, which are relevant to PSNWR. These include Article 21 of the ACHPR (Ratification and Enforcement) Act (ACHPR 2004), which expresses the right of African states to PSNWR. This Article has a caveat, which provides that states shall exercise PSNWR in the exclusive interest of the people, such that 'in no case shall a people be deprived of the benefits arising from the exercise of this right' (of PSNWR), as provided in Article 21 (1) of the ACHPR 2004. Hence, in the case of spoliation, disposed people shall have the right to lawful recovery of property and adequate compensation. This includes the fact that in the case of expropriation or nationalisation of foreign private assets or investments by African countries on the premise of PSNWR, the TNCs/MNCs whose assets or investments are expropriated or nationalised are entitled to adequate compensation, as provided in the second ambit of Article 21 (2). Also, Article 21 (3) of the ACHPR 2004 provides that natural wealth and resources of African states shall be freely disposed of by the government of these states to promote international economic cooperation, on the premise of mutual respect and equitable exchange premised on international law. Accordingly, Article 21 (4) of the ACHPR 2004 provides that natural wealth and resources of African states shall be freely disposed to strengthen African unity and solidarity. In the course of natural resources development for the full benefit of the people, such as to enhance economic sovereignty of African sovereign states, Article 21 (5) of the ACHPR 2004 empowers African countries to eliminate all forms of foreign exploitation. Besides, Article 22 of the ACHPR 2004 on the 'right to development' imposes a duty, on African countries and thus the governments of these countries, associated with 'the right to development', by promoting and accomplishing economic, social and cultural development, in the interest of their countries, and thereby ensuring that their people enjoy the common heritage of mankind. Accordingly, Article 24 of the ACHPR 2004 on 'environmental protection' provides that 'all peoples shall have the right to a general satisfactory environment favourable to their development.' Also, Article 25 of the ACHPR 2004 on 'teaching, education and publication' involves the responsibility of African states to promote and ensure, through teaching, education and publication, how to respect the rights and freedoms contained in the Charter and to understand, recognise and observe them as well as the corresponding obligations and duties associated with them.

Given that the provisions of each of the foregoing Articles of the ACHPR (Ratification and Enforcement) Act (ACHPR 2004), namely Articles 21, 22, 24 and 25, advocate and espouse the duties embedded in the rights of African states on PSNWR, there is a need for the Nigerian state, represented by governments in the country, to accomplish these duties and obligations of government in the course of petroleum development operations in the country. Doing so, would enhance the wellbeing of Nigeria and its citizens, particularly the wellbeing of the oil-rich Delta region, including the wellbeing of the citizens and environment of the region, during petroleum development in the communities of the region.

\footnotetext{
African Commission on Human and Peoples' Rights, 'African Charter on Human and Peoples' Rights' $<$ http://www.achpr.org/instruments/achpr/> Accessed 20 November, 2019.

${ }^{2}$ The International Justice Resource Center (IJRC), 'Regional Systems' < https://ijrcenter.org/regional/> Accessed 20 November, 2019; UN $\mathrm{OHCHR}$, Regional Office for South-East Asia, 'Regional human rights systems in other parts of the world: Europe, the Americas and Africa' $<$ https://bangkok.ohchr.org/programme/other-regional-systems.aspx > Accessed 20 November, 2019.

${ }^{3}$ ACHPR (Ratification and Enforcement) Act, No.3 1983, Cap A9 Laws of the Federation of Nigeria (LFN) 2004 (hereinafter called 'ACHPR 2004').

${ }^{4}$ AG Ondo State v AG Federation \& 33 Ors [2002] 9 NWLR (Pt. 772) 729.
} 
Although the ACHPR 2004 has robust provisions relating to the duties of government inherent in PSNWR, including ECOSOC rights, such as the right to a healthy (clean, safe and non-harmful) environment ${ }^{1}$ favourable to their development, ${ }^{2}$ it is a subsidiary law to the 1999 CFRN (as amended). ${ }^{3}$ Consequently, the provisions of the CFRN on human rights (under 'Fundamental Rights' ${ }^{4}$ and 'Fundamental Objectives and Directive Principles of State Policy') $)^{5}$ would prevail instead of the provisions of the ACHPR 2004, given the hierarchical nature of the application and enforcement of domestic laws in Nigeria.

\subsection{National Human Rights Commission (NHRC) Act}

Associated with the Nigerian version of the ACHPR (the ACHPR 2004), is the National Human Rights Commission Act, 1995, as amended by the NHRC Act, 2010, which was enacted in Nigeria, in compliance with the UNGA Resolution 52/128 of 12 December, 1997. This Resolution of the UNGA enjoins all member-states of the UN to establish national human rights institutions to promote and protect human rights in each member-state of the UN, in order to enhance the promotion, protection and enforcement of human rights in its domestic jurisdiction. ${ }^{6}$

\subsection{The Nigeria Extractive Industries Transparency Initiative (NEITI) Act}

The NEITI Act, 2007, concerning transparency in the EIOs and other related matters, was enacted to achieve Nigeria's effort aimed at domesticating the widely internationalised EITI. ${ }^{7}$ Nigeria enacted this Act, as part of its effort to also comprehensively reform its petroleum industrial sector, among other reasons, to reduce poverty and thereby enhance socio-economic growth and prosperity, appropriate and prudent protection of the environment, and to strengthen governance and other public-sector institutions and organisations associated with EIOs, to enhance SD in the country. ${ }^{8}$

\subsection{Other Nigeria's (Domestic) Laws Ranging from the 1999 Constitution of the Federal Republic of Nigeria (CFRN) (as amended), the Petroleum Act, 1969, to Other Subsidiary Laws Governing Petroleum Development in the Country}

Apart from the Petroleum Act, $1969,{ }^{9}$ which is the principal law governing the Nigerian petroleum industry, and the 1999 CFRN (as amended), there are several subsidiary laws governing petroleum development operations in Nigeria. The Petroleum Act is a legislation which provides for the development of petroleum from the territorial waters and the continental shelf of Nigeria and to vest the ownership of and all on-shore and off-shore revenues from petroleum resources derivable therefrom in the Federal Government and for all other matters incidental thereto. There are regulations, rules, guidelines, standards, policies and state practice made pursuant to the Petroleum Act. Principal among the regulations made pursuant to the Petroleum Act is the Petroleum (Drilling and Production) Regulations, 1969, which are made under powers conferred by Section 9 (1) of the Act, captioned 'Regulations'. Other Nigeria's subsidiary laws governing petroleum development operations in the country include the ACHPR 2004 and the NEITI Act discussed above. The rest of Nigeria's subsidiary laws governing petroleum development operations include the Oil Pipelines Act, ${ }^{10}$ Petroleum Profits Tax Act

\footnotetext{
${ }^{1}$ UNEP, Healthy Environment, Healthy People (UNEP 2016); E. T. Bristol-Alagbariya (2018 [n16]) 13 and 72.

2 Section 20, 1999 CFRN (as amended) captioned 'Environmental Objectives'.

${ }^{3}$ Section 1, 1999 CFRN (as amended) is captioned 'Supremacy of the Constitution'; per Kayode Eso JSC, in Kalu v Odili [1992] 5 NWLR (Pt. 240) 130 at 188 SC; per Udo Udoma JSC in Rabiu v State [1980] 2 SCR, 117; AG (Bendel State) v AG (Federation) \& 22 Ors. [1982] 3 NCLR 1 SC; Doherty v Balewa [1961] All NLR 631; AG (Federation) v AG (Abia State) \& 35 Ors (No. 2) [2002] 6 NWLR. (Pt. 764), 542905, [2002] 6 Judgements of the Supreme Court of Nigeria (MJSC) 1; K. M. Mowoe, Constitutional Law in Nigeria (Malthouse Press 2008) 34-41; E. Malemi, The Nigerian Constitutional Law (Princeton Publishing Co. 2012) 61-67.

${ }^{4}$ Chapter IV, Sections 33 - 46, 1999 CFRN (as amended) captioned 'Fundamental Rights'; E. Malemi, Administrative Law (Princeton Publishing Co. 2012) 85-86.

${ }^{5}$ Chapter II, Sections 13 - 24, 1999 CFRN (as amended) captioned 'Fundamental Objectives and Directive Principles of State Policy'; E. Malemi (n24) 260-275.

${ }^{6}$ UNGA Resolution 52/128 of 12 December, 1997, on National Institutions for the Promotion and Protection of Human Rights; homepage of the National Human Rights Commission of Nigeria (NHRCN) <https://www.nigeriarights.gov.ng/index.php > Accessed 20 November, 2019.

${ }^{7}$ Homepage of the EITI <https://eiti.org/> Accessed 20 November, 2019; The UNGA Resolution 62/274 of 11 September, 2008, captioned 'Strengthening Transparency in Industries'<http://www.un.org/en/ga/search/view doc.asp?symbol=A/RES/62/274> Accessed 20 November, 2019; EITI, 'UN Resolution on the EITI' <https://eiti.org/publishers/united-nations-general-assembly> Accessed 20 November, 2019 ; C. Rose, International Anti-Corruption Norms: Their Creation and influence on Domestic Legal Systems (Oxford University Press 2015) 139; EITI, 'History of the EITI: How It All Started, Where We Went and Where We Are Now'<https://eiti.org/history> Accessed 20 November, 2019.

${ }^{8}$ NEITI, 'Brief History of NEITI'<http://www.neiti.gov.ng/index.php/aboutus/brief-history-of-neiti> Accessed 29 August, 2019; N. Shaxson, Nigeria's Extractive Industries Transparency Initiative Just a Glorious Audit? (Royal Institute of International Affairs 2009) 2; EITI, 'History of the EITI: How It All Started, Where We Went and Where We Are Now' (n28); U. Igwe, 'Periscoping The Nigeria's NEITI Act 2007' $<$ http://saharareporters.com/2011/01/31/periscoping-nigeria\%E2\%80\%99s-neiti-act-2007> Accessed $20 \quad$ November, 2019; NEITI, 'EITI'<http://www.neiti.gov.ng/index.php/about-eiti> Accessed 20 November, 2019.

${ }^{9}$ Petroleum Act (formerly Petroleum Decree 1969 [Petroleum Act, 1969, Cap 350 LFN 1990, now Cap P10, LFN 2004).

${ }^{10}$ Oil Pipelines Act, 1958 (Cap 338 LFN 1990, now Cap 07, LFN 2004).
} 
(PPTA) ${ }^{1}$ Nigerian National Petroleum Corporation (NNPC) $A c t,{ }^{2}$ and the National Oil Spill Detection and Response Agency (NOSDRA) Act. ${ }^{3}$ Also, the Department of Petroleum Resources (DPR), which is the regulator of the Nigerian petroleum industry and the technical arm of the Ministry of Petroleum Resources (MPR), existing in reality as the Petroleum Inspectorate Department (PID) indicated in Section 10 of the NNPC Act, has its guidelines, standards and procedures, governing petroleum resources development operations in the country. Besides, there is the Niger Delta Development Commission (NDDC) Act and the Nigerian Oil and Gas Industry Content Development Act.

There are yet other Nigerian laws that are indirectly associated with petroleum resources development operations, and those related to particular aspects of these resources development operations in the country. Some of these laws include the Environmental Impact Assessment (EIA) Act, ${ }^{4}$ National Environmental Standards and Regulations Enforcement Agency (NESREA) Act, ${ }^{5}$ the Companies and Allied Matters Act (CAMA), as well as the Energy Commission of Nigeria (ECN) Act $^{6}$ and many regulations associated with petroleum development operations in Nigeria. For instance, regarding oil spill, there are the Oil Spill and Oily Waste Management Regulations, 2011, and the Oil Spill Recovery, Clean-up, Remediation and Damage Assessment Regulations, 2011, which regulations are made by NOSDRA. Accordingly, there are various environmental regulations developed by the Federal Government (FG) through NESREA, some of which may be associated with petroleum development operations in Nigeria. These regulations include the National Environmental (Noise Standards and Control) Regulations, 2009 (which is to ensure tranquillity of the human environment or surrounding and its psychological wellbeing by regulating noise levels) and the National Environmental (Coastal and Marine Area Protection) Regulations, 2010 (which is a regulatory framework for the application of anticipatory, precautionary and preventive approaches, so as to avoid deterioration of the coastal and marine environment). ${ }^{7}$

\subsection{The NNPC Act as a Relevant Legal Framework}

Another law concerning petroleum development operations in Nigeria is the NNPC Act, 1977, which was enacted to dissolve the Nigerian National Oil Corporation (NNOC), establish the NNPC and empower it to engage in all commercial activities regarding the petroleum industry and to enforce all regulatory measures relating to the general control of the petroleum sector through its PID. ${ }^{8}$ This Act established the NNPC as a vertically integrated national oil company (NOC), charged with the responsibility to perform all of the sectoral functions, duties and responsibilities, such as engaging in the exploration, production, marketing and supply activities of petroleum. The NNPC operates in all phases of the value chain of the petroleum industry, namely upstream, midstream and downstream monopoly. It engages in the Nigerian petroleum industry as a commercial entity, operator as well as a regulator of the industry, empowered to enforce all regulatory measures associated with the general control of the industry. ${ }^{9}$

The NNPC (Nigeria's commercial and regulatory petroleum corporation), ${ }^{10}$ represents the FG in the grant of petroleum concessions such as Oil Exploration Licence (OEL), Oil Prospecting Licence (OPL), Oil Mining Lease (OML) and other petroleum development contracts, which include Productions Sharing Contract (PSCs), Joint Ventures (JVs), and Service Contracts (SCs), ${ }^{11}$ beside associated arrangements of these contracts such as various forms of Memorandum of Understanding (MoU), as well as fall-outs of these concessions, contracts and arrangements.

\subsection{The EIA Act, NESREA Act and NOSDRA Act as Relevant Legal Frameworks}

First, the EIA Act institutionalised formal or statutory EIA in Nigeria, based on Principle 17 of the Rio Declaration on Environment and Development, 1992, and the USA's National Environmental Policy Act (NEPA)

\footnotetext{
${ }^{1}$ Petroleum Profits Tax Act (PPTA 1959, [Cap 354 LFN 1990 [now Cap P13 LFN 2004]).

${ }^{2}$ NNPC Act ([formerly NNPC Decree, Decree No. 33 of 1977] Cap 320 LFN 1990 and now Cap N123 LFN 2004 [hereinafter called 'NNPC Act 2004']).

${ }^{3}$ NOSDRA Act, 2006

${ }^{4}$ EIA Act (Decree No. 86 of 1992) Cap 86 LFN 1992 (now Cap E12 LFN 2004).

${ }^{5}$ NESREA Act, 2007.

${ }^{6}$ ECN Act, No. 62 of 1979 [No. 1 of 1983], now Cap E10 LFN 2004).

${ }^{7}$ NESREA, 'Laws \& Regulations'<http://www.nesrea.gov.ng/publications-downloads/laws-regulations/> Accessed 20 November, 2019.

${ }^{8}$ NNPC Act 2004.

${ }^{9}$ Section 5, NNPC Act 2004, captioned 'General Duties of the Corporation'; Section 6, NNPC Act, entitled 'Powers of the Corporation'; Section 10, NNPC Act, captioned 'Petroleum Inspectorate'; M. C. Thurber et al, NNPC and Nigeria's Oil Patronage Ecosystem (Program on Energy and Sustainable Development, 2010).

${ }^{10}$ Section 5, NNPC Act 2004, captioned 'General Duties of the Corporation'; Section 6, NNPC Act, captioned 'Powers of the Corporation'; Section 10, NNPC Act, entitled 'Petroleum Inspectorate'.

${ }^{11}$ Y. Omorogbe, Oil and Gas Law in Nigeria (Malthouse Press 2001) 38-54; G. Etikerentse, Nigerian Petroleum Law (Dredew Publishers 2014) 60-124; K. G. Kingston, Oil and Gas Laws: A Guide for International Practitioners (LAP LAMBERT Academic Publishing 2018) $178-183$.
} 
of 1969, which came into force in January 1970, as the first EIA around the globe. ${ }^{1}$ By virtue of the EIA Act, all development projects or activities of any public and private sector institution or organisation of the Nigerian economy, which may likely or to a significant extent affect the environment, are to be subjected to EIA. ${ }^{2}$ In the process, petroleum development project activities are 'mandatory EIA study activities' ${ }^{3}$ Based on ongoing and increasingly advancing global effort of the UN on the environment and development towards achieving SD, benchmarked EA process and practice are designed to safeguard the vitality, diversity and productivity of natural resources, and overall nature as well as natural systems on Planet Earth. ${ }^{4}$

Second, the NESREA Act, 2007, is also associated with the EIA process and practice in Nigeria. This Act repealed the Federal Environmental Protection Agency (FEPA) Act, ${ }^{5}$ and thus exists as the successor of the FEPA Act that gave birth to the defunct FEPA, Nigeria's apex environmental protection and regulatory agency. ${ }^{6}$ FEPA was regulating Nigeria's EIA process and practice when the EIA was formally institutionalised in the country.

Third, the NOSDRA Act, 2006, which provides for the establishment of NOSDRA (as the institutional framework of the Act) and other related matters, its institutional framework (NOSDRA) are associated with petroleum development operations.

\subsection{The Niger-Delta Development Commission (NDDC) (Establishment) Act}

The NDDC (Establishment) Act, ${ }^{7}$ hereinafter simply called 'the NDDC Act'), is a law enacted to repeal the Oil Minerals Producing Areas Development Commission (OMPADEC) Decree, 1992, ${ }^{8}$ and among other things, establish a new Commission (the NDDC) to ensure that funds allocated by oil and gas producing companies and other companies, including NGOs, are properly utilised to execute PPPs to develop and cater for the overall wellbeing of the oil-rich Niger Delta region. ${ }^{9}$

\subsection{The Nigerian Oil and Gas Industry Content Development Act (NOGICDA)}

The NOGICDA, $2010,{ }^{10}$ promotes the participation of Nigerian indigenous companies and manpower in the Nigerian oil and gas industry by ensuring that priority is given to Nigerian indigenous oil and gas companies and the utilisation of Nigerian human and material resources for the provision of goods and services in the industry within acceptable operational quality and Health, Safety and Environment (HSE) standards. ${ }^{11}$ By and large, the NOGICDA is designed to stimulate the Nigerian political economy towards SD, such that it should measurably accomplish aspects of the FG's duties inherent in PSNWR in the course of petroleum development in Nigeria. Consequently, sections 26, 27 and 28 of NOGICDA should exceptionally benefit the oil-rich communities of the Niger Delta region as catchment areas of petroleum development operations in Nigeria. ${ }^{12}$

\subsection{The Allocation of Revenue (Federation Account) Act}

The Allocation of Revenue (Federation Account) Act is an Act to prescribe the basis for distribution of revenue accruing to the Federation Account between the Federal and State Governments and the Local Government Councils in the States; the formula for distribution among the States inter se; the proportion of the total revenue of each State to be contributed to the State Joint Local Government Account; and for other purposes connected therewith. ${ }^{13}$ The Act limits the power of state governments for borrowing money, in such a manner that state

\footnotetext{
${ }^{1}$ The EIA Decree, Decree No. 861992 (now EIA Act, Cap E12, LFN 2004); A. Gilpin, Environmental Impact Assessment (EIA): Cutting Edge for the Twenty-First Century (Cambridge University Press 1995) 2 and 5-7; E. T. Bristol-Alagbariya, Participation in Petroleum Development: Towards Sustainable Community Development in the Niger Delta (Centre for Energy Petroleum \& Mineral Law \& Policy [CEPMLP]/Dundee University Press [DUP] 2010) 146-147.

${ }^{2}$ Section 2, EIA Act, LFN 2004, is captioned 'Restriction on Public or Private Project without Prior Consideration of the Environmental Impact'.

${ }^{3}$ Schedule of the EIA Act, LFN 2004, captioned 'Mandatory Study Activities'.

${ }^{4}$ Principle 1, Rio Declaration on Environment and Development, 1992.

${ }^{5}$ Section 36, NESREA Act, 2007, captioned 'Repeal of Cap. F10 LFN, 2004'.

${ }^{6}$ Section 1, FEPA (Amendment) Decree (Decree No. 59 of 1992), FEPA Act, Cap F10 LFN 2004, captioned 'Establishment of the Federal Environmental Protection Agency'.

${ }^{7}$ The Niger-Delta Development Commission (Establishment) Act, No. 6 LFN 2000, Cap N86 LFN 2004 (otherwise called the NDDC Act 2004); The Niger Delta Development Commission (Establishment) Amendment Act, 2017.

${ }^{8}$ The Oil Minerals Producing Areas Development Commission Decree, Decree No. 23 of 1992; A. K. Horsfall, The OMPADEC Dream (Lacing Business Park Modern Business Centre Imprint Publications 1999).

${ }^{9}$ Sections 7 and 8, NDDC Act, 2004, respectively captioned 'Functions and Powers of the Commission', and 'Powers of the Board'; NDDC,

'About Us'<http://www.nddc.gov.ng/about\%20us.html> Accessed 20 November, 2019.

${ }^{10}$ Nigerian Oil and Gas Industry Content Development Act (NOGICDA) No. 2 of 2010.

${ }^{11}$ Detail Solicitors, 'NOGICDA Sites for Reference Materials' $<$ https://www.detailsolicitors.com/media/archive1/articles/Oil.pdf $>$ Accessed 20 November, 2019.

12 Section 26, NOGICDA, 2010, captioned 'Personnel for Local Office'; Section 27, NOGICDA 2010, captioned 'Office in Community of Operation'; Section 28, NOGICDA, 2010, captioned 'First Consideration for Employment and Training'.

${ }^{13}$ The Allocation of Revenue (Federation Account) Act, 1982, Cap A15 LFN 2004, made pursuant to Section 162 of the 1999 CFRN (as amended), captioned 'Distributable Pool Account'; Sections 162 - 168 of the Constitution is captioned 'Public Revenue'.
} 
governments would not borrow money from the revenue allocated to local government councils under the Act. ${ }^{1}$

\subsection{Global and Other Relevant International Institutional Frameworks}

The UNGA is the institutional framework of the UNGA Resolution on PSNWR and the UNGA Resolution on the Rights of Persons Belonging to National or Ethnic, Religious and Linguistic Minorities. The Office of the UN Secretary-General is the institutional framework of the UN Global Compact. The entire UN system is the institutional framework of the UN SRJR process on the environment and development towards SD.

\subsection{Institutional Frameworks of PSNWR Relating to Petroleum Development in Nigeria}

Applicable Nigerian laws discussed above include the CAMA, which institutional framework is the Corporate Affairs Commission (CAC) ${ }^{2}$ and the ECN Act, which institutional framework is the ECN. ${ }^{3}$ The ECN is the highest organ of government that coordinates all energy sources and activities in Nigeria. The ECN Act has the potential to help guarantee security of supply of energy resources' products, such as petroleum products to Nigerian citizens, as a way of accomplishing government social responsibilities (GSRs) to the citizens and the general public in the country. Petroleum products like gasoline (petrol), diesel fuel, liquefied petroleum gas (LPG), and such other fuels as fuel oil and kerosene, and petrochemical products, which include pharmaceuticals, solvents, fertilizers, pesticides, synthetic fragrances, and plastics, are essential for the wellbeing of Nigerian citizens. ${ }^{4}$

\subsection{Institutional Frameworks of the ACHPR}

The two main institutional frameworks of the African Charter on Human and Peoples' Rights (ACHPR) (otherwise referred to as the African charter system or African Regional charter system on human rights and fundamental freedoms) are the African Commission on Human and Peoples' Rights (otherwise called the 'African Commission') and the African Court on Human and Peoples' Rights (otherwise called the 'African Court').

\subsubsection{The African Commission on Human and Peoples' Rights (African Commission)}

The African Commission, established in 1987, is mentioned in Articles $30-61$ of the ACHPR (Ratification and Enforcement) Act (ACHPR 2004). The Commission is a quasi-judicial body, regulator and the principal engineering force that promotes and protects human rights in African countries as well as the chief enforcement organ that oversees and monitors the implementation of the ACHPR in these countries. ${ }^{5}$ The Commission makes recommendations, which are not legally binding but only advisory towards the promotion, protection and enforcement of the human and peoples' rights and fundamental freedoms. It may use its 'good offices' to secure the resolution of human rights cases at any stage of their proceedings at the African Court. It has no mechanism that can compel states to abide by its decisions and recommendations. ${ }^{6}$ Thus, the Commission only complements the efforts of the African Court of Human and Peoples' Rights, given that it is the Court that makes binding decisions on cases of abuse and violation of human rights.

\subsubsection{The African Court on Human and Peoples' Rights (The African Court)}

The African Court on Human and Peoples' Rights (The African Court) (hereinafter called 'The Court') is an African Continental Court established by a protocol, which was adopted by member-states of the AU in Ouagadougou, Burkina Faso, in June 1998, and came into force on 25 January, 2004. The Court was established to adjudicate cases of abuse and violation of human rights and fundamental freedoms in Africa, and to complement and reinforce the functions of the African Commission to promote, protect and enforce the abuse and violation of these rights and freedoms enshrined in the ACHPR in member-states of the AU. ${ }^{7}$

\footnotetext{
${ }^{1}$ Section 8, Allocation of Revenue (Federation Account) Act 2004, captioned 'Limit on Power of State Governments for Borrowing Money'. ${ }^{2}$ Section 1, CAMA, Cap 59 LFN 1990 (now Cap C20 LFN 2004), captioned 'Establishment of the Corporate Affairs Commission'; homepage of the CAC <http://new.cac.gov.ng/home/> Accessed 20 November, 2019.

${ }^{3}$ Section 1, ECN Act, Cap E10 LFN 2004, captioned 'Establishment of the Energy Commission of Nigeria'.

${ }^{4}$ S. C. Dike, Energy Security: The Case of Nigeria and Lessons from Brazil, Norway and the UK (Pearl Publishers 2015) 154-211; Encyclopædia Britannica, 'Petroleum' <https://www.britannica.com/science/petroleum> Accessed 20 November, 2019; NIIR Project Consultancy Services, 'Petroleum Products: Refining and Distillation (Lubricants, Waxes and Petrochemicals) Manufacture of Crude Oil, Gasoline, Kerosene, Absorbent, Oils, and Fuel Oils, Petroleum $<$ https://www.entrepreneurindia.co/Document/Download/pdfanddoc-334415-.pdf $>$ Accessed 20 November, 2019; Goal 7, UNSDGs, captioned 'Affordable and Clean Energy'; Y. Omorogbe and A. O. Ordor (eds), Ending Africa's Energy Deficit and the Law: Achieving Sustainable Energy for All (Oxford University Press, 2018).

${ }^{5}$ Article 30, ACHPR 2004, captioned 'Mandate of the Commission'; African Union, Legal Affairs: Judicial and Human Rights Institutions $<$ https:/au.int/legal $>$ Accessed 20 November, 2019; African Union, 'African Union Commission (AUC)' $<$ https://au.int/en/organs/commission $>$ Accessed 20 November, 2019; African Commission on Human and Peoples' Rights, 'African Charter on Human and Peoples' Rights' (n18).

${ }^{6}$ African Union, AU Organs: Judicial and Human Rights Institutions $<$ https://au.int/en/organs/cj $>$ Accessed 20 November, 2019.

${ }^{7}$ African Union, Legal Affairs: Judicial and Human Rights Institutions (n60); African Court on Human and Peoples' Rights, 'Frequently Asked Questions' <http://www.african-court.org/en/index.php/faqs/frequent-questions $>$ Accessed 20 November, 2019; African Court on Human and Peoples' Rights, 'Establishment of the Court' <http://www.african-court.org/en/index.php/about-us/establishment $>$ Accessed 20
} 
The Court (after being established in 1998 and expanded between 2004 and 2008, to become the African Court of Justice and Human Rights), ${ }^{1}$ gives binding decisions on cases of abuse and violation of human rights and fundamental freedoms brought before it. The Court has two chambers, one exercising jurisdiction over general legal matters, while the other exercises jurisdiction over cases of human rights. ${ }^{2}$ When required, the Court may interpret its decision. The Court also assumes jurisdiction on cases requiring its advisory opinion and decision and thereby promotes amicable settlement of non-adversarial disputes on abuse and violation of human and peoples' rights and fundamental freedoms in an advisory manner. ${ }^{3}$

The Court officially commenced its operations in Addis Ababa, Ethiopia in November 2006, and in August 2007, it moved to its seat in Arusha, the United Republic of Tanzania. The Court has its rules, which it harmonised with the African Commission. In July 2008, the AU Assembly decided and adopted a Protocol to merge the African Court of Justice (which did not become operational) with the African Court on Human and Peoples' Rights into an African Court of Justice and Human Rights (ACJHR), which protocol has been signed and ratified by many of AU's member-states. ${ }^{4}$.

\subsection{National Human Rights Commission of Nigeria (NHRCN) as Institutional Framework of the NHRC Act}

The NHRCN is the institutional framework of the NHRC Act, 1995/2010, which provides avenues for public enlightenment, research, and dialogue, so as to create awareness on issues of human rights. ${ }^{5}$ This Commission, which serves as an extra-judicial mechanism for the promotion, protection and enforcement of human rights in Nigeria, is headed by the Executive Secretary, who is its Chief Executive Officer (CEO). The Commission has State offices in all the Thirty Six States of Nigeria and the Federal Capital Territory (FCT), Abuja. ${ }^{6}$

\subsection{NEITI as the Institutional Framework of the NEITI Act}

The Nigeria Extractive Industries Transparency Initiative (NEITI) is the body known and/or established as the institutional framework of the NEITI Act, 2007. ${ }^{7}$ Based on the underlying principle of the global EITI, the NEITI is founded on the philosophical premise that SD efforts are achievable in developing countries, including Nigeria, which are richly endowed with major natural resources but plagued by the resource-curse, when the governments of these countries recognise and perform their sovereign duty to manage their country's wealth accruing from major natural resources EIOs for the overall benefit of their citizens and all-embracing development and prosperity of their countries. As indicated above, Nigeria's effort at promoting the EITI is mainly targeted towards sanitising the Nigerian petroleum industry towards overall public good in the country. ${ }^{8}$

\subsection{NNPC and DPR as Institutional Frameworks of the NNPC Act}

The provisions of the NNPC Act, 1977 (now NNPC Act, 2004) generated two institutional frameworks, namely the NNPC and the DPR (which historically evolved and still exist in reality as the Petroleum Inspectorate).

Sections 5, 6 and 10 of the NNPC Act, respectively captioned 'General Duties of the Corporation', 'Powers of the Corporation' and 'Petroleum Inspectorate' empower the NNPC to operate as a vertically integrated NOC in charge of all phases of the value chain of the petroleum industry, namely upstream, midstream and downstream sectors of the industry, as well as the regulator of the industry. In addition to the NNPC's exploration activities, it is engaged in petroleum refining operations, production of petrochemicals and other petroleum products as well as transportation and marketing of these products. ${ }^{9}$ In 1988 , the NNPC was

November, 2019; African Court on Human and Peoples' Rights, 'Welcome to the African Court' <http://www.africancourt.org/en/index.php/12-homepage1/1-welcome-to-the-african-court> Accessed 20 November, 2019; African Union, 'African Union Commission (AUC)' (n60).

1 Ibid; Médecins Sans Frontières, 'The African Commission and African Court for Human Rights' <https:/guide-humanitarianlaw.org/content/article/3/the-african-commission-and-african-court-for-human-rights/> Accessed 20 November, 2019; Article 1, Protocol to the ACHPR on the Establishment of an African Court on Human and Peoples' Rights, (the Protocol), adopted by the OAU in Ouagadougou, Burkina Faso, in June 1998, and came into force on 25 January, 2004.

${ }^{2}$ Médecins Sans Frontières (n63).

${ }^{3}$ African Court of Justice and Human Rights, 'Advisory Proceedings' <http:/www.african-court.org/en/index.php/cases/2016-10-17-16-1935\#finalised-opinions $>$ Accessed 20 November, 2019.

${ }^{4}$ African Union, AU Organs: Judicial and Human Rights Institutions (n60); Protocol on the Statute of the African Court of Justice and Human Rights adopted by the AU on 1 July, 2008, and date of last signature on 4 February, 2019; African Union Commission (AUC), African Union Handbook 2016: A Guide for Those Working with and within the African Union (AUC and the New Zealand Ministry of Foreign Affairs and Trade 2016) 102.

${ }^{5}$ Homepage of the NHRCN (n27); S. O. Nnamani, 'Institutional Mechanisms for Human Rights Protection in Nigeria: An Appraisal' [2011] 2 Journal of International Law and Jurisprudence, 128-137.

${ }^{6}$ Homepage of the NHRCN (n27).

${ }^{7}$ Section 1, NEITI Act, 2007, captioned 'Establishment of the Nigeria Extractive Industries Transparency Initiative'; homepage of NEITI $<$ http://www.neiti.gov.ng/index.php> Accessed 20 November, 2019; N. Shaxson (n29) 1.

${ }^{8}$ U. Igwe (n29); NEITI, 'EITI'<http://www.neiti.gov.ng/index.php/about-eiti > Accessed 20 November, 2019.

${ }^{9}$ NNPC, 'Corporate Information' <https://www.nnpcgroup.com/About-NNPC/Pages/Corporate-Information.aspx > Accessed 20 November, 
commercialised into Strategic Business Units (SBUs), encompassing the entire spectrum of petroleum industry operations, such as exploration and production, gas development, refining, distribution, petrochemicals, engineering, and commercial investments, in order to make it become a competitive global energy company. ${ }^{1}$

Concerning the DPR, it may be stated that based on the historical development of the NNPC and the Ministry of Petroleum Resources (MPR), which superintends over the NNPC in the Nigerian civil service system, it evolved as the NNPC's technical arm and regulator of the petroleum industry, existing in reality as the PID, also called the 'Petroleum Inspectorate', as stipulated in Section 10 of the NNPC Act, $2004 .^{2}$

The DPR has statutory responsibility to ensure compliance with laws, regulations and guidelines pertaining to the Nigerian petroleum industry. ${ }^{3}$ The discharge of these responsibilities involves monitoring of operations at drilling sites, production wells, production platforms and flow-stations, crude oil export terminals, refineries, storage depots, pump stations, retail outlets, any other locations where petroleum is either stored or sold, and all pipelines carrying crude oil, natural gas and petroleum products. ${ }^{4}$ Also, based on its responsibilities as the regulator of the Nigerian petroleum industry, the DPR has developed many operational guidelines, policies, standards, procedures and licences, permits, authorisations and practices governing the Nigerian petroleum industry and in effect petroleum operations in the country. These include the DPR's Environmental Guidelines and Standards for the Petroleum Industry in Nigeria (EGASPIN), 1991 (updated in 2002), and its Petroleum (Drilling and Production) Regulations such as the guidelines for the accreditation and registration of general purpose oil industry service companies, which were amended in 1988, among many others, which are increasingly being designed and updated ${ }^{5}$ to ensure and enhance quantitative HSE processes and, in general, good oilfield practices, which may be considered to mean 'all those things that are generally accepted as good and safe in the carrying on of petroleum operations' ${ }^{6}$ throughout the value chain of petroleum industrial operations in Nigeria.

\subsection{Institutional Frameworks of the EIA Act, NESREA Act and NOSDRA Act}

The institutional frameworks associated with the EIA Act are the EA Department of the FMEnve and NESREA superintended over by the FMEnve. Accordingly, the institutional frameworks of the NOSDRA Act are NOSDRA and the FMEnve, which is the overseer of NOSDRA in Nigeria's federal civil service system. NESREA and NOSDRA are agencies of the FGN as well as parastatals of the FMenve in Nigeria's federal civil service system. The FMEnve is the overall institutional framework of the NOSDRA, EIA and NESREA Acts. Accordingly, the FMEnve is the overseer of NOSDRA, EIA and NESREA in the same system. ${ }^{7}$

5.6 The Niger Delta Development Commission (NDDC) as the Institutional Framework of the NDDC Act The NDDC is an agency of the FG and institutional framework of the NDDC Act, which was established and commissioned to execute the NDDC Act in order to realise the Government's objectives arising from petroleum resources development operations in the oil-rich communities of the Niger Delta region. The mandate of the NDDC is to represent the FG to physically develop, socio-economically empower and tackle the ecological and other environmental problems and challenges arising from petroleum resources development operations in the oil-rich communities of the Delta region, in order to achieve SD in the region. ${ }^{8}$

\subsection{The Nigerian Content Development and Monitoring Board (NCDMB) as the Institutional Framework of NOGICDA}

The NCDMB, provided for under Section 4 of the Nigerian Oil and Gas Industry Content Development Act

2019

${ }^{1}$ Ibid.

${ }^{2}$ Section 10, NNPC Act, 2004, captioned 'Petroleum Inspectorate'; DPR, 'In the Beginning' <https://www.dpr.gov.ng/history-of-dpr/> Accessed 20 November, 2019.

${ }^{3}$ Section 10, NNPC Act, 2004, captioned 'Petroleum Inspectorate.'

${ }^{4}$ Ibid.

${ }^{5}$ DPR, 'Guidelines'<https://www.dpr.gov.ng/dpr-guidelines/> Accessed 20 November, 2019.

${ }^{6}$ Law Insider, 'Definition of good oil-field practice' $<$ https://www.lawinsider.com/dictionary/good-oilfield-practice $>$ Accessed 20 November, 2019; Drilling Lexicon, 'Good Oilfield Practice'<http://www.iadclexicon.org/good-oilfield-practice/> Accessed 20 November, 2019.

${ }^{7}$ Section 5, NOSDRA Act, 2006, captioned 'Objectives of the Agency'; Section 6, NOSDRA Act, 2006, captioned 'Functions of the Agency', Section 7, NOSDRA Act, 2006, captioned 'Special Functions of the Agency'; Section 1, NESREA Act, 2007, captioned 'Establishment of National Environmental Standards and Regulations Enforcement Agency'; Section 7, NESREA Act, 2007, captioned 'Functions of the Agency'; Federal Republic of Nigeria, 'Federal Ministry of Environment' <http://www.nigeria.gov.ng/index.php/2016-04-06-08-4029/executive/147-federal-ministry-of-environment> Accessed 20 November, 2019; Department of Climate Change, Federal Ministry of Environment, 'Federal Ministry of Environment' <http://climatechange.gov.ng/about-us/ministry-of-environment/> Accessed 20 November, 2019; N. S. Benebo, Appropriate Mechanisms for Environmental Protection and Sustainable Development in Nigeria: An Advocate's Viewpoint (NESREA 2014), xviii, 17, 55-56, 60-68 and 496.

${ }^{8}$ Section 1, NDDC Act, 2004, captioned 'Establishment of the Niger-Delta Development Commission'; E. T. Bristol-Alagbariya, Governance Towards Sustainable Development in Nigeria: The Role of Strategic Assessment of Decisions \& Actions (CEPMLP/DUP 2013) 224. 
(NOGICDA) Act, 2010, ${ }^{1}$ is the institutional framework of the NOGICDA, to guide, coordinate, monitor and implement the provisions of the Act. The NCDMB is established to implement the provisions of this Act with a view to ensuring a measurable and continuous growth of Nigerian content in all petroleum arrangements, projects, operations, activities or transactions in the Nigerian petroleum industry.

\subsection{The Federation Account Allocation Committee (FAAC) and the Joint Local Government Account Allocation Committee (JAAC) as Institutional Frameworks of the Allocation of Revenue (Federation Account) Act}

Section 6 of the Allocation of Revenue (Federation Account) Act, 2004, establishes FAAC and outlines its functions. The functions of this Committee are: (a) to ensure that allocations made to the States from the Federation Account are promptly and fully paid into the treasury of each State on the basis and terms prescribed by this Act; and (b) to report annually to the National Assembly regarding performance of the function specified in item (a) hereof. ${ }^{2}$ Section 7 of the Allocation of Revenue (Federation Account) Act also establishes JAAC for each State and outlines its functions, namely to ensure that allocations made to the Local Government Councils in the State from the Federation Account and from the State concerned are promptly paid into the State Joint Local Government Account and distributed to Local Government Councils in accordance with the provisions of any law made in this regard by the House of Assembly of the State. ${ }^{3}$

It is pertinent to mention at this juncture that studies are continually revealing that the results of development proposals are better when the affected, concerned and interested members of the public are empowered to participate in the decision-making process of such proposals. Therefore, legal, institutional and other regulatory measures governing petroleum resources development operations in Nigeria should promote genuine participation and derivation of fair, equitable and socially-just impact-benefits from these resources development operations by Nigerian citizens, especially citizens of the oil-rich Delta region, ${ }^{4}$ towards sustainable EIOs and overall public good in the country. ${ }^{5}$

\subsection{Ministry of Niger Delta Affairs (MNDA) as an Institution Established to Develop the Oil-rich Delta Region}

The MNDA is a FG institution established to cater for the development of the oil-rich Niger Delta region, consequent upon petroleum development operations in the oil-rich communities of the region and overall context of nation-building in the federation. ${ }^{6}$ The immediate reasons that prompted President Yar'Adua to create the MNDA on 10 September, 2008, include, addressing the crises in the oil-rich Delta region, aggravated by youth restiveness and militancy, in the region, due to decades of adverse consequences of petroleum development operations in the region. President Yar'Adua created the Ministry to address the age-long neglect, marginalisation and deprivation of the minority ethnic Delta region in the history and political development of Nigeria.

\subsection{Conclusion}

In concluding, it may be appropriate to state that the spotlight of this paper on some global and other benchmarked international standards and practices associated with PSNWR, which are considered in the context EIOs, as exemplified by petroleum development operations in Nigeria, demonstrates the need for good, dynamic and effective laws as well as viable, strong, dynamic and efficient institutions in the country. Such laws and institutions are required to properly and/or robustly accomplish the duties of resources-rich developing countries ingrained in PSNWR, in the course of EIOs such as petroleum development operations in Nigeria. On the platform of good, dynamic and effective laws, policies, standards, programmes and state practices, viable and efficient institutions are able to improve GSR measures in Nigeria, so as to strengthen governance to achieve generic public good, overall prosperity and environmentally-sound and socio-economically equitable SD in the country. There is thus a need for Nigeria and other resources-rich developing countries to domesticate relevant widely acknowledged and accepted benchmarked SD-oriented soft law mechanisms, in the form of regulatory standards and practices, in order to properly govern natural resources development operations in the context of PSNWR. These benchmarked SD-oriented soft law mechanisms have the potential of boosting GEG and other

\footnotetext{
${ }^{1}$ Section 4, NOGICDA, 2010, captioned 'Role of Nigerian Content Monitoring Board'.

${ }^{2}$ Section 6, Allocation of Revenue (Federation Account) Act 2004, captioned 'Establishment of Federation Account Allocation Committee and Functions'.

${ }^{3}$ Section 7 (3), Allocation of Revenue (Federation Account) Act 2004; Section 7, Allocation of Revenue (Federation Account) Act 2004, captioned 'Establishment of Joint Local Government Account Allocation Committee for each State and functions'.

${ }^{4}$ E. T. Bristol-Alagbariya (2010 [n43]) 3, 45, 325, 328 and 331; A. M. Lawal et al, 'Public Participation in EIA: the Case of West African Gas Pipeline and Tank Farm projects in Nigeria', [2013] 31 (3) Impact Assessment and Project Appraisal, 226-231, especially 231.

${ }^{5}$ E. T. Bristol-Alagbariya (2010 [n43]) 13, 18, 31, 42, 44, 317, 321, 323-324, 326-327, 329-331, 334-335; E. T. Bristol-Alagbariya (2013 $[\mathrm{n} 79])$.

${ }^{6}$ Homepage of the Ministry of Niger Delta Affairs (MNDA) <http://www.nigerdelta.gov.ng/index.php> Accessed 20 November, 2019.
} 
aspects of GSR that could effectively accomplish the duties of Nigeria inherent in PSNWR, in the course of petroleum development operations in the oil-rich Delta region of the country, towards sustainable petroleum development operations in the region.

This paper also emphasises that studies are continually revealing that the results of development proposals are better when the affected, concerned and interested members of the public are empowered to participate in the decision-making process of such proposals. We therefore recommend that legal, institutional and other regulatory measures governing petroleum and other EIOs in Nigeria should be designed to achieve genuine participation and derivation of fair, equitable and socially-just impact-benefits by affected Nigerian citizens and communities in the course of EIOs, towards human wellbeing and overall public good in the country. Particularly, we recommend interactive participation and genuine SD-oriented engagement of citizens of the petroleum resources producing communities of the Delta region in the course of petroleum EIOs in the region, towards improved socio-economic empowerment, poverty alleviation measures and all-embracing SD in the region, as well as overall GEG, good governance and environmentally-sound and socio-economically equitable sustainable development in Nigeria.

We recommend that various departments, levels and institutions of government, especially government petroleum regulatory institutions and agencies, should, in the exercise of their respective functions, ensure that citizens and communities of the Delta region are accorded fair, equitable and socially-just impact-benefits; this should be done, even in the context and frameworks of environmental and social performances of oil and gas companies, especially MNOCs, operating in the oil-rich communities of the region.

A follow-up study would, on the premise of actual performances and/or performance indicators of relevant government institutions established on the basis of their respective enabling laws, further examine the degree of efficacy of these institutions and overall associated GSR designed to fulfil the duties of Nigeria ingrained in PSNWR, with particular regard to petroleum development in the country.

\section{References}

Abbott K. W. and Snidal D., 'Hard and Soft Law in International Governance' [2000] 54 (3) International Organization, 421-456.

Benebo N. S., Appropriate Mechanisms for Environmental Protection and Sustainable Development in Nigeria: An Advocate's Viewpoint (NESREA 2014), xviii, 17, 55-56, 60-68, 496.

Bristol-Alagbariya E. T., Governance Towards Sustainable Development in Nigeria: The Role of Strategic Assessment of Decisions \& Actions Delta (Centre for Energy Petroleum \& Mineral Law \& Policy [CEPMLP]/Dundee University Press [DUP] 2013), 224.

Bristol-Alagbariya E. T., Participation in Petroleum Development: Towards Sustainable Community Development in the Niger Delta (CEPMLP/DUP 2010), 3, 13, 18, 31, 42, 44, 45, 146-147, 325, 317, 321, $323-324,326-331,334,335$.

Bristol-Alagbariya E. T., Petroleum Development \& the Environment in Rivers State Nigeria: Fallouts of the UNEP Report on Ogoniland, Environmental Regulatory Standards \& Sustainable Development Laws \& Practices (LAP Lambert Academic Publishing 2018), 1, 13, 43, 66, 72, 74.

Dike S. C., 'Decommissioning and Abandonment of Oil and Gas Facilities Legal Regime in Nigeria: Any Lesson from Norway, the UK and Brazilian Legal Frameworks' [2017] 6 (1) The Journal of Property Law and Contemporary Issues, 169-183.

Dike S. C., Energy Security: The Case of Nigeria and Lessons from Brazil, Norway and the UK (Pearl Publishers 2015), 154-211.

Etikerentse G., Nigerian Petroleum Law (Dredew Publishers 2014), 60-124,

Gilpin A., Environmental Impact Assessment (EIA): Cutting Edge for the Twenty-First Century (Cambridge University Press 1995), 2, 5-7.

Guzman A. T. and Meyer T. L., 'International Soft Law' [2010] 2 (1) The Journal of Legal Analysis, 171-225.

Horsfall A. K., The OMPADEC Dream (Lacing Business Park Modern Business Centre Imprint Publications 1999.

International Institute for Environment and Development (IIED) and World Business Council for Sustainable Development (WBCSD), Breaking New Ground: Mining, Minerals, and Sustainable Development: The Report of the MMSD Project (Earthscan 2002).

Kingston K. G., Oil and Gas Laws: A Guide for International Practitioners (LAP LAMBERT Academic Publishing 2018), 178-183.

Lawal A. M., Bouzarovski S. and Clark J., 'Public Participation in EIA: the Case of West African Gas Pipeline and Tank Farm projects in Nigeria', [2013] 31 (3) Impact Assessment and Project Appraisal, 226-231.

Lyons D., 'The Correlativity of Rights and Duties' [1970] 4 (1) Nô̂s, 45-55.

Malemi E., Administrative Law (Princeton Publishing Co. 2012), 85-86.

Malemi E., The Nigerian Constitutional Law (Princeton Publishing Co. 2012), 61-67, 260-275. 
Mowoe K. M., Constitutional Law in Nigeria (Malthouse Press 2008), 34-41.

Nnamani S. O., 'Institutional Mechanisms for Human Rights Protection in Nigeria: An Appraisal' [2011] 2 Journal of International Law and Jurisprudence, 128-137.

Omeje K. (ed), Extractive Economies and Conflicts in the Global South: Multi-Regional Perspectives on Rentier Politics (Ashgate Publishing 2008).

Omeje K., High Stakes and Stakeholders: Oil Conflict and Security in Nigeria (Routledge 2016).

Omorogbe Y., Oil and Gas Law in Nigeria (Malthouse Press 2001), 38-54.

Omorogbe Y. and Ordor A. O. (eds), Ending Africa's Energy Deficit and the Law: Achieving Sustainable Energy for All (Oxford University Press, 2018)

Public Sector Group Poverty Reduction and Economic Management (PREM) Network, Reforming Public Institutions and Strengthening Governance (The International Bank for Reconstruction and Development [IBRD]/The World Bank 2000).

Rose C., International Anti-Corruption Norms: Their Creation and influence on Domestic Legal Systems (Oxford University Press 2015), 139.

Rose R. and Peiffer C., Bad Governance and Corruption: Political Corruption and Governance (Palgrave Macmillan 2019), xiii.

Schrijver N., Sovereignty over Natural Resources: Balancing Rights and Duties (Cambridge University Press 1997), 1-3.

Shaxson N., Nigeria's Extractive Industries Transparency Initiative Just a Glorious Audit? (Royal Institute of International Affairs 2009), 2.

Skjærseth J. B., Stokke O. S. and Wettestad J., 'Soft Law, Hard Law, and Effective Implementation of International Environmental Norms' [2006] 6 (3), Global Environmental Politics, 104-120.

Stevens P. J., 'The Resource Curse Revisited Appendix: A Literature Review' [2015] The Royal Institute of International Affairs, 1-42.

Terry H. T., 'Legal Duties and Rights' [1903] 12 (4) The Yale Law Journal, 185-212.

UNEP, Healthy Environment, Healthy People (UNEP 2016).

UK Department for Environment, Food and Rural Affairs (DEFRA), Sustainable Development Indicators in Your Pocket 2009: An Update of the UK Government Strategy Indicators (Crown 2009), 119-120.

World Commission on Environment and Development (WCED), Our Common Future (Oxford University Press 1987), 8, 40 and 43. 